\title{
The Connection between Education and Religious Insight with Madrasah Teachers' Work Motivation in Indonesia
}

\author{
Anis Fauzi \& Eni Nur'aeni \\ Islamic Public Institute of Sultan Maulana Hasanuddin Banten \\ J1. Jendral Sudirman No.30 Serang, ZIP Code 42118, Banten Province, Indonesia \\ E-mail: Jantera_Anis@yahoo.com
}

Received: Feb. 3, 2016 Accepted: May 26, 2016 Published: May 26, 2016

doi:10.5296/jse.v6i2.9569 URL: http://dx.doi.org/10.5296/jse.v6i2.9569

\begin{abstract}
This study aimed to determine the reality of education and religious insight of madrasah teachers as well as the relationship between education and religious insights with madrasah teachers' work motivation in Serang District, Banten Province. The method used is descriptive method with case study approach and quantitative data analysis. The research sites were at Sultan Agung Madrasah Tirtayasa, Nurul Huda Madrasah Baros and Raudhatul Ulum Madrasah Anyer. The respondents were 50 councilors in each madrasah. Data collection techniques used in the study were questionnaires, observations, and interviews. Based on the data analysis using statistical approaches and the development of a linear regression formula and multiple regression, correlation values are quite high among the variables of educational insights $\left(\mathrm{X}_{1}\right)$ with the variables of madrasah teachers' work motivation $(\mathrm{Y})$; and between variables of religious insight $\left(\mathrm{X}_{2}\right)$ with the madrasah teachers' work motivation $(\mathrm{Y})$; as well as between the variables of religious and education insight $\left(\mathrm{X}_{1}\right.$ and $\mathrm{X}_{2}$ ) with the variables of madrasah teachers' work motivation $(\mathrm{Y})$.
\end{abstract}

Key words: insight, education, religious, work motivation, madrasah teachers. 


\section{Introduction}

In Act No. 20 of 2003 on Indonesia National Education System Chapter 1 Article 1 it is stated that "education is a conscious and deliberate effort to create an atmosphere of learning and the learning process so that learners are actively developing the potential for themselves to have the spiritual power of religion, self-control, personality, intelligence, noble character, and skills needed for themselves, society, nation and state."

One of the main components of education and teaching is the teachers. In the school system, the position and role of teachers are very important and strategic. Their duties cannot be treated easily, because they run a critical mission in instilling religious, ethics, social and aesthetics values of life. Regarding the matter, every madrasah teachers must have adequate national awareness, with a way of understanding specific parts of Islam, such as the insight on jurisprudence, theology, Sufism, and the history of Islamic civilization.

According to Article 1, paragraph 1 of Law No. 14 Year 2005 on Teachers and Lecturers in Indonesia it is stated that the definition of the teachers are professional educators with the primary task of educating, teaching, guiding, directing, training, assessing and evaluating students on early childhood education, formal education, basic education and secondary education.

Teachers as one of the humane components of education have a responsibility to bring students to a certain level of maturity or a certain maturity. Therefore, teachers do not act merely as a teacher only, but more than that is as an educator. Teacher is one of the main actors in the process. Teacher is a profession that is currently regarded and demanded by people who attain the job similar as other professions. That is, the paradigm that the teaching profession should bring adequate profit has formed among the public.

Without realizing it, sometimes the teacher becomes a target for the cause of the deterioration of education quality. Teachers are even considered as the ringleader. Teachers in the initial concept are different to teachers in the contemporary concept. In the past, teachers are those who have insight, wisdom, and science. It is now the opposite, teacher is nothing more than a functionary who merely seek a livelihood (Asyumardi Azra, 2000: 165). Because of their position began to shift, according to Aminuddin Rashad, the concept of the teachers should be revitalized, restored to the initial concept of its role as a credible leader forever. As an educator, teachers responsible for discovering and developing the potential contained within the students towards positive developments.

Carrying out such a task is not easy, because the one they are facing is human who have different characteristics. Therefore, in addition to expertise, an educator should really have a high dedication as a consequence and a sense of responsibility, so that they can perform their duties optimally.

Motivation can come from within and outside us, but when viewed from the strength and its maturity; motivation arising from within will be more stable and steady as compared with the motivation that comes from the surrounding environment. Motivation can be stimulated by external factors, but the motivation was growing inside oneself. Motivation can be said to be 
the driving force in people. Someone who has a strong motivation will have a lot of energy to do the teaching process. Motivation can serve as a spur to effort and achievement. The existence of a good motivation in teaching will give a good result. In other words, by the existence of motivation, the value of a good education will be born.

In general, the purpose of education is to help the child's development in achieving the level of maturity, which includes the development of physical, emotions, attitudes, morals, insight and skills potential in order to become a responsible adult.

Based on the background explained above, the main problem in this study is: How are the education insight, religious insight, and work motivation of madrasah teachers in three Islamic Education Foundation in Serang District of Banten Province, as well as the relationship of education and religious insight with the work motivation of madrasah teachers on three Islamic Education Foundation in Serang District of Banten Province?

In accordance with the main problem, the purpose of this study is to determine the insight of education, insight of religious, and work motivation of madrasah teachers in three Islamic Education Foundation in Serang District of Banten Province, as well as the relationship between insights of education and insight of religious with the work motivation of madrasah teachers at three Islamic Education Foundation in the Serang District of Banten Province.

The results of the study are expected to be useful for the Board of Islamic Education in terms of understanding the general idea of education insight, religious insight, and work motivation of the madrasah teachers. For the teachers, the results can be used as a reference in an effort to increase insight about education, religious, and motivation of their work. As for local governments and communities around the study site, it can be one of the agenda of improving the quality of teachers and the quality of madrasah management as an Islamic educational institution.

\section{Methodology}

Based on the objectives, this research used descriptive method, a method that is intended to give a clearer picture of the social situations (Nasution, 2000: 24). In this case, the social situation of madrasa teachers' work motivation that allegedly correlated with educational insight and religious insight.

Meanwhile, according to its form, this study used case study method; a deep study method focuses on the environmental aspects of the social thing. In this case are the aspect of work motivation of teachers, teachers' religious insight and teachers' education insight in the three Islamic Education Foundation in the Serang District of Banten Province.

Population is all members of a group of humans, animals, events, or objects that live together in one place and are planned to become the target of the conclusion of the final results of a study (Sukardi, 2003: 53). Meanwhile, according to Suharsimi (2010: 173), population is the entire subject of a research. In one hand, according to Nasution (2000: 86), population is the number of people who have to be investigated. 


\subsection{Prticipnts}

In this study, the population is the entire board of teachers who teach in three Islamic Education Foundations which have been used as the research sites. The three Islamic Education Foundations in this study are YPI Sultan Agung Tirtayasa (78), YPI Nurul Huda Baros (75), and YPI Raudatul Ulum Anyer (74).

According to Sukardi (2003: 54), sample is a portion of the population that is selected to be the source of certain data. Meanwhile, according to Suharsimi (2010: 174), sample is partially representative of the population being studied. Subsequently, according to Nasution (2000: 86), sample is a certain amount of the overall population.

In this case, the researcher determined size of sample study with 150 people. In detail of the samples are 50 teachers council of Islamic Board Foundation Sultan Agung Tirtayasa, 50 teachers council of Islamic Board Foundation Nurul Huda Baros, and 50 teachers council of Islamic Education Foundation Raudhatul Ulum Anyer.

\subsection{Instruments}

The data required in this research acquired through the distribution of questionnaires, guidelines for non-participatory observation, interviews, and documentation study. In this case, the questionnaires were made into three kinds; the first questionnaire focused on the insights of madrasah teacher about education; the second questionnaire focused on religious insight of madrasah teachers; and the third questionnaire focused on the work motivation of madrasah teachers in the research sites. Data collected from questionnaires were processed by using Likert Scale. The respondents who answered (a) given score of 5, the respondents who who answered (d) given score of 2, and respondents who answered (e) given score of 1 .

\subsection{Data Analysis}

The data from questionnaires then processed and statistically analyzed using product moment correlation analysis technique with this formula:

$$
r_{x y}=\frac{N \sum X Y-\left(\sum X\right)\left(\sum Y\right)}{\sqrt{\left.\left\{N \sum X^{2}-\left(\sum X\right)^{2}\right\} N \sum Y^{2}-\left(\sum Y\right)^{2}\right\}}}
$$

The magnitude of the effect of variable $\mathrm{X}$ to variable $\mathrm{Y}$ (coefficient determination) is calculated using the formula: $\mathrm{Cd}=\mathrm{r}^{2} \times 100 \%$.

\section{Result}

Description of the data in this study includes the average value, standard deviation, frequency of distribution, median and mode, as well as the histogram graph of the three variables of the study. The raw data were processed using descriptive statistical method. Descriptive statistical method is more likely to relate with the collection and processing of the data, as well as the resume presentation. The description of the descriptive calculation described below. 


\subsection{Insight of Education}

The range of the variables minimum score of the Madrasah Teachers' Education Insight is 24 and the maximum score is 96 . Based on the calculation of descriptive statistics it is obtained that the minimum score is 48 and the maximum score is 89 . While for the average score, it is obtained that the score is 68.08 , the standard deviation is 17.85 , median 67.95 , and mode 67 , 90.

To measure the level of Madrasah Teachers' Education Insight, standard quartile level was used as follows:

\begin{tabular}{|c|c|c|c|c|c|c|c|}
\hline 100 Respondents & $\mathrm{X}$ & 20 & item $\mathrm{x}$ & 5 & $=$ & 10000 & (very good \\
\hline 100 Respondents & & 20 & item $\mathrm{x}$ & 4 & $=$ & 8000 & (good) \\
\hline 100 Respondents & & 20 & item $\mathrm{x}$ & 3 & $=$ & 6000 & (fair) \\
\hline 100 Respondents & & 20 & item & 2 & $=$ & 4000 & (bad) \\
\hline 00 Respondents & & 20 & item & 1 & $=$ & 2000 & (very bad) \\
\hline
\end{tabular}

Total score of respondents' answers to the variable of Madrasah Teachers' Education Insight is 6837. This score, when inserted into the quartiles standard level stated above, are located in good position, which means that the Madrasah Teachers' Education Insights in the research sites categorized as good.

The level of Madrasah Teachers' Education Insights which is $70.92 \%$ in this study categorized as good based on the calculation as follows:

$$
\text { Mean }=\underset{\text { Maximum Score }}{\text { Mean }} \times 100 \%=\frac{68,08}{96} \times 100 \%=70,92 .
$$

\subsection{Insights of Religious}

The minimum score range of variable Madrasah Teachers'Religious Insight is 27 and the maximum score is 135. Based on the calculations, the minimum score is 81 and the maximum score is 115 . As for the average, the score obtained is 96.85 ; the standard deviation is 25.27 , median 97.11, and mode 97.89. To measure the level of religious insight, standard quartile level was used as follows:

\begin{tabular}{|c|c|c|c|c|c|c|c|}
\hline 100 Respondents & K & 20 & item $x$ & 5 & $=$ & 10000 & (very good \\
\hline 100 Respondents & & 20 & item $x$ & 4 & $=$ & 8000 & (good) \\
\hline 100 Respondents & & 20 & item $x$ & 3 & $=$ & 6000 & (fair) \\
\hline 100 Respondents & & 20 & item $\mathrm{x}$ & 2 & $=$ & 4000 & (bad) \\
\hline 00 Respondents & & 20 & item $\mathrm{x}$ & 1 & $=$ & 2000 & (very bad) \\
\hline
\end{tabular}

Total score of respondents' answers to variable of Madrasah Teachers' Religious Insight based on data obtained in the attachment is 9,569. This score, when added to the standard 
quartile levels above lies in good position, means that religious insight of madrasah teachers is in good category. See this figure.

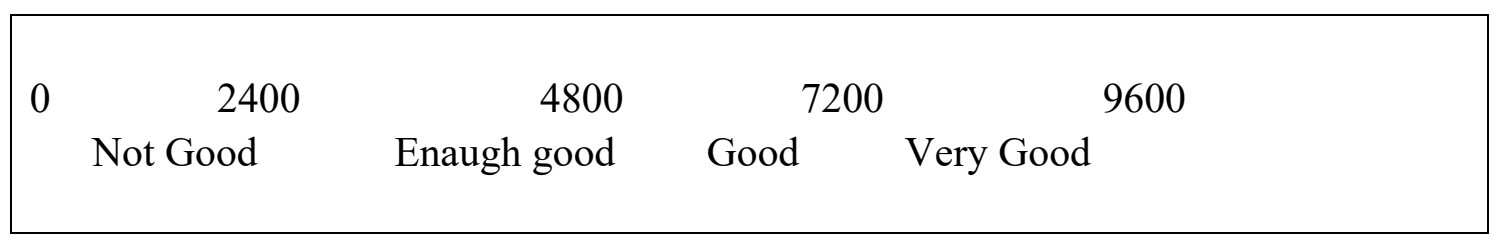

Religious Insights level of Madrasah Teachers in this study is about $71.74 \%$, making it lies in higher category based on the following calculation:

$$
\begin{aligned}
\text { Mean }= & \frac{\text { Mean }}{\text { Maximum Score }} 100 \%=\underline{96,85} \times 100 \%=71,74 .
\end{aligned}
$$

As for the distribution of variable data can be described in terms of frequency distribution and histogram shown in this table this figure.

\begin{tabular}{|c|c|c|c|c|c|}
\hline \multicolumn{2}{|c|}{ Interval Grade } & \multirow{2}{*}{$\frac{F}{11}$} & \multirow{2}{*}{$\begin{array}{r}\text { Midpoint } \\
83\end{array}$} & \multicolumn{2}{|c|}{ Real limit } \\
\hline 81 & 85 & & & 82,5 & 85,5 \\
\hline 86 & 90 & 13 & 88 & 85,5 & 90,5 \\
\hline 91 & $\begin{array}{l}-95 \\
\end{array}$ & 17 & 93 & 90,5 & 95,5 \\
\hline 96 & $-\quad 100$ & 23 & 98 & 95,5 & $-100,5$ \\
\hline 101 & $-\quad 105$ & 16 & 10 & $100,5-$ & 105,5 \\
\hline 106 & -110 & 8 & 108 & $105,5-$ & 110,5 \\
\hline 111 & $-\quad 115$ & 7 & 113 & 110,5 & $-\quad 115,5$ \\
\hline
\end{tabular}

Table 1. Distribusi Frekwensi

\subsection{Work Motivation of Madrasah Teachers}

The minimum score range of Madrasah Teachers' work motivation variable is 0 and the maximum score is 25 . Based on the calculation of descriptive statistics, it is obtained that the minimum score is 11 and the maximum score is 24 . As for the average score 17.80 was obtained; standard deviation of 4.61; the median of 17.55 , and 16.50 for mode.

To measure the level of work motivation of Madrasah Teachers standard quartile levels of

\begin{tabular}{|c|c|c|c|c|c|c|c|c|}
\hline 100 Respondents & $\mathrm{x}$ & 20 & item & $\mathrm{x}$ & 5 & $=$ & 10000 & (very good) \\
\hline 100 Respondents & $\mathrm{x}$ & 20 & item & $\mathrm{x}$ & 4 & - & 8000 & (good) \\
\hline 100 Respondents & $\mathrm{x}$ & 20 & item & $\mathrm{x}$ & 3 & 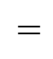 & 6000 & (fair) \\
\hline 100 Responden & $\mathrm{x}$ & 20 & item & $\mathrm{x}$ & 2 & $=$ & 4000 & (bad) \\
\hline 00 Respondents & $\mathrm{K}$ & 20 & item & $\mathrm{x}$ & 1 & $=$ & 2000 & (very bad) \\
\hline
\end{tabular}
variables was used as follows:

Total score of respondents' answers to the variable Work Motivation of Madrasah Teachers based on the attached data is 1,781 . This score, when inserted into the standard quartile above 
lies in a good position, means that Work Motivation of Madrasah Teacher is categorized as "good". See this appendix.

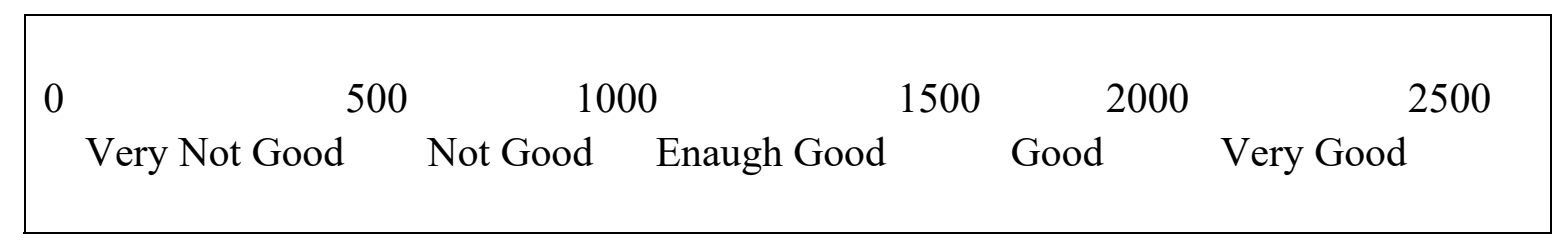

The average level of Madrasah Teachers' Work Motivation in this study was $71.20 \%$. This score is considered as good category based on the following calculation:

$$
\text { Mean }=\frac{\text { Mean }}{\text { Maximum score }} \times 100 \%=\frac{17,50}{25} \times 100 \%=71,20
$$

The distribution of variable data of Madrasah Teachers' Work Motivation described in terms of the frequency distribution shown in this table.

FREQUENCY DISTRIBUTION TABLE WORK TEACHER MOTIVATION MADRASAH

\begin{tabular}{|lll|l|l|ll|}
\hline \multicolumn{2}{|l|}{ Interval Grade } & F & Midpoint & \multicolumn{2}{l|}{ Real limit } \\
\hline 12 & - & 12 & 4 & 11,5 & $10,5-$ & 12,5 \\
\hline 13 & - & 14 & 14 & 13,5 & $12,5-$ & 14,5 \\
\hline 15 & - & 16 & 21 & 15,5 & $15,5-$ & 16,5 \\
\hline 17 & - & 18 & 21 & 17,5 & $16,5-$ & 18,5 \\
\hline 19 & - & 20 & 16 & 19,5 & $18,5-$ & 20,5 \\
\hline 21 & - & 22 & 12 & 21,5 & $20,5-$ & 22,5 \\
\hline 23 & - & 24 & 12 & 23,5 & $22,5-24,5$ \\
\hline
\end{tabular}

\section{Hypothesis testing}

1. The relationship between Education Insights with Work Motivation of Madrasah Teachers

To determine the relationship between education insight with work motivation of madrasah teachers, regression and correlation analysis were used. Based on the calculation $\mathrm{a}=7.62$ and $\mathrm{b}=0.15$ were obtained. By inserting the $\mathrm{a}$ and $\mathrm{b}$ into the regression equation of $\mathrm{Y}$ over $\mathrm{X}_{1}$; $\mathrm{Y}$ $=7.62+0.15 \mathrm{X}_{1}$. To test the truth of $\mathrm{X}_{1}$ and $\mathrm{Y}_{1}$ the linearity and significance of regression test was conducted. The analysis of the various sources of variation shown in this table. 
Table 2. Anava For Simple Linear Regression

\begin{tabular}{|l|l|l|r|l|l|}
\hline Su.Va & db & JK & RJK & Fh & Fi \\
\hline Total & 100 & 33324.00 & & & \\
\hline Reg a & 1 & 32184.36 & 32184.36 & 28,02 & 3.11 \\
Reg b & 1 & 253.39 & 253.39 & & \\
Rest & 98 & 886.25 & 9.04 & & \\
\hline Suitable & 28 & 330,51 & 11.80 & 1.49 & 1.62 \\
Error & 70 & 555,74 & 7.94 & & \\
\hline
\end{tabular}

From the data in that table, the linearity test results in $\mathrm{F}$ count equal to 1.49; whereas from the distribution list $\mathrm{F}$ with a significance level $\alpha=0.05$, degrees of freedom $\mathrm{db} 1=28$ and $\mathrm{db} 2=$ $70,1.62 \mathrm{~F}$ table was acquired. If we compare both of them, it turns out that $\mathrm{F}$ count is smaller than $\mathrm{F}_{\text {table, or }} 1.49$ less than 1.62 (see attached Statistics Table of $\mathrm{F}_{\text {Table). It can be inferred }}$ that the regression equation $\mathrm{Y}=7,62+0.15 \mathrm{X}_{1}$ is linear.

The linearity test then followed by test of significance. From the table of variance analysis (ANOVA) $\mathrm{F}_{\text {count }}=28.02$ is obtained; while on the $\mathrm{F}$ distribution table with degrees of freedom $\mathrm{db} 1=1$ and $\mathrm{db} 2=98$, and the confidence level $\alpha=0.05 \mathrm{~F}_{\text {table }}=3.11$ was obtained. If we compare both of them, it turns out that $\mathrm{F}_{\text {count }}(28.02)$ is greater than the $\mathrm{F}_{\text {table }}(3.11)$, then $\mathrm{H}_{0}$ is rejected, because it is not verified and this means that $\mathrm{H}_{1}$ is accepted. It can be concluded that coefficient regression is significant.

Furthermore, the correlation test between $\mathrm{X}_{1}$ and $\mathrm{Y}$ was conducted. Based on the simple correlation analysis obtained the coefficient of ry $_{1}=0.47$ and coefficient of determination $r^{2}$ $\mathrm{y}_{1}=0.20$. From the significance test it was obtained the correlation of $\mathrm{t}_{\text {count }}=5.27$. This simple correlation coefficient turned out to be significant after being tested by $t$ test. This is shown by the $t_{\text {count }}(5,21)$ which is bigger than $t$ table $(1.67)$ at $\alpha=0.05$ and degrees of freedom of 98 .

The relationship between $\mathrm{X}_{1}$ and $\mathrm{Y}$ was partially tested by controlled $\mathrm{X}_{2}$, from the calculation it is obtained that the coefficient of $\mathrm{ry}_{1.2}=0.38$ and coefficient of determination $\mathrm{r}^{2} \mathrm{y}_{1.2}=0.15$. The partial correlation coefficient was significantly tested using the $t$ test. From the calculation it is obtained that the $\mathrm{t}_{\text {count }}=4.03$. While $\mathrm{t}_{\text {table }}$ at the real level $\alpha=0.05$ and with degree of freedom is $97, t_{\text {table }}=1.67$ obtained. Thus, if compared, the $t_{\text {count }}(4: 03)$ is bigger than $t_{\text {table }}(1.67)$. This means that $H_{0}$ is rejected because it is not verified and $H_{1}$ or partial correlation between $\mathrm{X}_{1}$ and $\mathrm{Y}$ with controlled $\mathrm{X}_{2}$ is significant was accepted.

With significance relationship between $\mathrm{X}_{1}$ with $\mathrm{Y}$ either simple or partial, it can be concluded that the first hypothesis is correct, that there is a positive relationship between education insight with work motivation of madrasah teachers and significantly tested.

2. Relationship between Religious Insights to Work Motivation Teacher Madrasah 
To determine the relationship between the religious insights with the work motivation of madrasah teachers, regression and correlation analysis was used. From the calculation a = 3.77 and $b=0.15$ were obtained. By entering the $a$ and $b$ in the regression equation of $\mathrm{Y}$ on $\mathrm{X}_{2}, \mathrm{Y}=3.77+0.15 \mathrm{X}_{2}$. To test the truth of $\mathrm{X}_{2}$ with $\mathrm{Y}$, linearity and significance of regression tests were conducted. The analysis of the various sources of variation is shown in this Table.

Table 3. Anava Untuk Regresi Linier Sederhana

\begin{tabular}{|l|c|r|r|l|l|}
\hline Su.Va & \multicolumn{1}{|l|}{$\mathrm{db}$} & $\mathrm{JK}$ & \multicolumn{1}{l|}{ RJK } & Fh & Fi \\
\hline Total & 100 & 33324.00 & & & \\
\hline Reg a & 1 & 32184.36 & 32184.36 & 14.77 & 3.98 \\
Reg b & 1 & 149.23 & 149.23 & & \\
Rest & 98 & 990.41 & 10.11 & & \\
\hline Suitable & 29 & 370,66 & 11.80 & 1.42 & 1.64 \\
Error & 69 & 619,74 & 7.94 & & \\
\hline
\end{tabular}

From the data shown in that table, the linearity test results in $F$ count of 1.42. While the distribution list $\mathrm{F}$ with a significance level $\alpha=0.05$, degrees of freedom $\mathrm{db} 1=29$ and $\mathrm{db} 2=$ $69 \mathrm{~F}$ table of 1.64 was obtained. When both of them were compared, $\mathrm{F}$ count (1.42) is smaller than $\mathrm{F}$ table (1.64) (see attached statistical tables of Table F). It can be inferred that the regression equation $\mathrm{Y}=3.77+0.15 \mathrm{X}_{2}$ is linear.

The linearity test then followed by a test of significance. From the table of variance analysis (ANOVA) $\mathrm{F}$ count $=14.77$ was obtained. While the $\mathrm{F}$ distribution table with degrees of freedom $\mathrm{db} 1=1$ and $\mathrm{db} 2=98$, the confidence level $\alpha=0.05, \mathrm{~F}$ table of 3.11 was obtained. If we compare both of them, it turns out that $F$ count $(14.77)$ is greater than the $F$ table 3.11 , then Ho is rejected because it is not verified and this means that $\mathrm{H}_{1}$ is accepted. It can be concluded that the regression coefficient is significant.

Furthermore, the correlation between $\mathrm{X}_{2}$ and $\mathrm{Y}$ was tested. From the simple correlation analysis it is obtained that the coefficient of $\mathrm{ry}_{2}=0.36$ and the coefficient determination of $r^{2} y^{2}=0.13$. From the significance correlation test, $t_{\text {count }}=3.82$ was obtained. This simple correlation coefficient turned out to be significant after being tested by $t$ test. This is evidenced by the $t_{\text {count }}$ that is greater than $t$ table 3.82 or greater than 1.67 at $\alpha=0.05$ and degrees of freedom 98 .

The relationship between $\mathrm{X}_{2}$ and $\mathrm{Y}$ partially tested by controlled $\mathrm{X}_{1}$ that results in the calculation of $y_{2.1}$ coefficient $r=0.38$ and coefficient of determination $r^{2} y_{2.1}=0.14$. The partial correlation coefficient significance was tested using the t test. The calculation results in the $t_{\text {count }}$ of 2.08. While $t_{\text {tableon }}$ the level of $\alpha=0.05$ and with degrees of freedom 98is 1.67. Thus, if compared, $\mathrm{t}_{\text {count }}$ is greater than $\mathrm{t}_{\text {table }}$ or 2.08 is greater than 1.67. It means that Ho is rejected because it is not verified and $\mathrm{H}_{1}$, where partial correlation of $\mathrm{X}_{2}$ and $\mathrm{Y}$ with $\mathrm{X}_{1}$ controlled is significant, is accepted.

With the significance relationship between $\mathrm{X}_{2}$ and $\mathrm{Y}$ either in simple or partial, it can be concluded that the second hypothesis is correct, that there is a positive relationship between religious insight and the work motivation of Madrasah Teachers. 
3. The relationship between Education Insight and Religious Insight with Madrasah Teachers' Work Motivation

To test the truth of the relationship between the variable $X_{1}$ and $X_{2}$ with variable $Y$, multiple regression coefficient significance tests was conducted by using $\mathrm{F}$ test. From the calculations, the amount of the $\mathrm{F}$ count equal to 16,64 . While based on the distribution list $\mathrm{F}$ with numerator degrees of $\mathrm{dk} 1=2$ and degrees of denominator freedom of $\mathrm{dk} 2=97$ at a significance level of $0.05, \mathrm{~F}$ count equal to 3.09 was obtained. If both of them are compared, the obtained $\mathrm{F}$ count (16.64) is greater than the $F$ table (3.09). Because the $F$ countis larger than $F$ table, then Ho is rejected because it is not verified and $\mathrm{H}_{1}$ is accepted. This means that the regression coefficient is significant.

In order to test the multiple relationships between variables $\mathrm{X}_{1}$ for 0,51 and determination coefficient $\mathrm{R}^{2} \mathrm{y}^{1.2}$ of 0.26 . To test the truth of the multiple correlation coefficient $\mathrm{F}$ test was used. The calculations result in the $\mathrm{F}$ count equal to 16.64 and at the significance level of 0.05 with degrees of freedom numerator $\mathrm{dk} 1=2$ and degrees of freedom denominator $\mathrm{dk} 2=$ $97, F_{\text {table }}=3.09$ was obtained. If both of them are compared, then the $F$ count $(16.64)$ is greater than the $\mathrm{F}$ table (3.09). Because the $\mathrm{F}$ count larger than $\mathrm{F}$ table, Ho is rejected because it is not verified and $\mathrm{H} 1$ is accepted. This means that multiple correlations are significant.

Thus, it can be concluded that the third hypothesis is correct, that is there is a positive relationship between education and religious insights to the work motivation of madrasah teachers received and very significantly tested.

\section{Discussion}

Insight of education is very important and determines the implementation or otherwise the learning objectives and educational goals implemented in the madrasah. Insight of educational achievement will encourage teachers to teach as high. The education to be achieved in the educational institutions results in residual quality with high academic achievement.

Teachers are expected to be able to foster a sense of educational insight positively accept of existing and created at the madrasah. Teachers can openly ask for help to stakeholders that exist in school to help them solving all the problems that they face. In addition, the need of encouragement from the school principal is regarded as the chairman and mentor of the teachers.

The creation of better educational insight is the ability that should be owned by every teacher in terms of mastery the basics of education, educational psychology, educational evaluation and planning education and teaching and learning strategies.

Insight of religious of a teacher has a significant contribution to the work motivation levels achieved by them; the headmaster needs to understand the behavior of the teachers who become his subordinates, both concerning the background behaved, strong motives, objectives, expectations and desires. Intended as a religious insight capability that should be 
possessed by madrasah teachers in showing mental attitude, mindset and certain behavior patterns that are based on values the implementation of the teachings of Islam in daily life.

Work motivation level of teachers is the actual ability of madrasah teachers, especially in terms of cognitive aspects without ignoring the aspect of affective and psychomotor aspects. To achieve a high motivation of madrasah teachers, efforts and supporting factors are required. Work motivation is intended as a teacher's ability to mobilize all its potential in order to make the program as an educator is successful. The ability to work in terms of coming to school, going to class, delivering learning programs, evaluating learning, enrichment, doing remedial teaching, evaluating the results of the learning process, and seek feedback from the entire learning program.

\section{Conclusion}

Based on the results of data processing and analysis, and hypothesis testing, it can be concluded that: Firstly, there is a positive and significant relationship between educational insight with madrasah teachers' work motivation shown by the $t_{\text {count }}$ of 5.27 which is greater than $t$ table value $(1,67)$ at a significance level of 0.05 . The pattern of relationship between two variables is expressed by the equation $\mathrm{Y}=7.62+0.15 \mathrm{X}_{1}$, which means that every change of one per cent of educational insight will lead to changes in work motivation of madrasah teacher of $0.15 \%$. Secondly, there is a positive and significant relationship between religiosity with work motivation of madrasah teachers who was shown by $3,82 \mathrm{t}$ count greater than $\mathrm{t}$ table (1.67) at significance level of 0.05 . The pattern of relationship between two variables is expressed by the equation $\mathrm{Y}=3.77+0,15 \mathrm{X}_{2}$, which means that every $1 \%$ change in religious insight will lead to changes in work motivation of madrasah teacher of $0.15 \%$. Thirdly, there is a significant positive relationship between education insight and religious insight together with madrasah teachers' work motivation shown by the calculated $\mathrm{F}$ count of 16.64 which is much greater than the $\mathrm{F}$ table 0 3.09 at the 0.05 level, so that is a significant multiple correlation coefficient. Based on the analysis of multiple correlation, multiple correlation coefficient calculation $\left(\mathrm{Ry}_{1.2}\right)$ of 0.51 and a coefficient of determination $\left(\mathrm{Ry}^{1.2}\right)$ of 0.26 were obtained.

\section{Acknowledgment}

The Author would like to Acknowledgment for contribution of teacher in Agung Madrasah Tirtayasa, Nurul Huda Madrasah Baros and Raudhatul Ulum Madrasah Anyer in Serang District, Banten Province, Indonesia.

\section{References}

Abudin Nata, (2006). Methodology of Islamic Studies, Jakarta, Publisher King GrafindoPersada.

Azyumardi Azra, (2000). Islamic Education: Tradition and Modernization Towards the Millennium, Jakarta: Logos Publishers.

Law No. 20 of 2003 on National Education System. 


\section{Macrothink}

Journal of Studies in Education

ISSN 2162-6952 2016, Vol. 6, No. 2

Law Number 14 Year 2005 on Teachers and Lecturers, Article 1, paragraph 1.

M. Arifin, (2006). Capita Selecta Islamic Education, Jakarta: Earth Literacy Publishers.

Nasution, (2000). Research Methodology, Bandung: Youth Rosdakarya Publishers.

Suharsimi, (2010). Research Procedure, Jakarta: Publisher Rineka.

Sukardi, (2003). Introduction to Educational Research Methodology, Jakarta: Earth Literacy Publishers.

Winardi, (2001). Motives and Motivation, Jakarta: Rajawali Publishers.

Yudrik Yahya, (2003). Insight Educational, Jakarta: Ministry of National Education. 